\title{
Effect of Activity-Based Learning on Student Learning Achievement in Construction Management
}

\author{
R. M. Sugandi, Suparno, Made Wena, Pribadi \\ Department of Civil Engineering \\ Universitas Negeri Malang \\ Malang, Indonesia \\ r.machmud.ft@um.ac.id
}

\author{
Hasan Ismail \\ National Chiao Tung University \\ Hsinchu, Taiwan
}

\begin{abstract}
This study aimed to investigate the advantages of using the ABL method incorporating experiential learning in a blended environment over the conventional learning. This research was an experimental research with a $2 \times 2 \times 2$ factorial design. The research participants were 56 students obtained using the saturation sampling technique. The data were collected using two methods namely test and non-test. The data were analyzed using a four-way analysis of variance (ANOVA). In the hypothesis tests, the significance level $(\alpha)$ used was 0.05 or $5 \%$. The results showed that there was; (1) a significant difference in student achievement and soft skill between groups of students taught by the ABL method and taught using conventional methods; (2) a significant difference in student achievement between student groups with high achievement motivation and with low achievement motivation; (3) a significant difference in student achievement between groups of students with high soft skill and with low soft skills; and (4) a significant interaction effect by using ABL model, achievement motivation, and soft skill on student achievement. Referring to the results of this study, learning in the course of construction management by using ABL could improve the ability to think critically and improve the soft skills and student achievement.
\end{abstract}

Keywords - activity-based learning, learning achievement in construction management

\section{INTRODUCTION}

The results of preliminary research conducted by the researchers on teaching and learning process, especially in the subject of construction management in the Department of Civil Engineering, Faculty of Engineering, State University of Malang, showed that almost $75 \%$ of the learning process is done conventionally. The learner-centered learning with content-based learning that all the material is delivered is in accordance with the curriculum and syllabus without giving much attention to the process and the interaction of learning in each lesson. The time allocation seems effective, but this kind of process positions students in a passive mode and hence the students get a low achievement.

Given the fact that the quality of learning process in Civil Engineering is not that optimal, it is necessary to develop an effective instructional approach which fulfils the relevant criteria in terms of its didactic, technical, and methodological aspects. Based on some theoretical and empirical studies in the literature, one of the viable strategies to solve the learning problem is by implementing the activity-based learning approach integrated with experiential learning in a blended learning format.

The use of the activity-based approach in the instructional process can encourage a positive shift of students' role, from passive to active learners. Moreover, it can develop cognitive, affective and psychomotor domains simultaneously, allowing students to achieve higher-order performance. On top of that, it can foster a deep approach to learning, in which students view learning as a process of conceptualizing concepts or facts (meaning orientation). Horsburgh stated that optimal learning occurs when there is an environment that is conducive to active learning [1]. This case concurs well with Petra stating that "for teaching to be effective, learning must take place" [2]

As a learning approach, the implementation of ABL requires a certain learning model/method to work with. In accordance with the principles of ABL, experiential learning is considered to fit the approach. Some studies in the field of technology and vocation showed that the implementation of experiential learning could significantly improve the learning outcomes [3]-[6]. Moreover, the inclusion of experiential learning in textbooks and activity-based learning was believed to be able to develop not only students' knowledge but also their technical skills and attitudes/soft skills [3], [7].

In experiential learning, knowledge is obtained through a combination of grasping and transforming experience [4]. Experiential learning is an instructional model based on Kolb's theory where learning is defined as the process by which knowledge is constructed through the transformation of experience [3]. The transformation of experience includes the link between the doing and the thinking. One will learn much better through active participation in the learning process. Experiential learning is constructed by a four stages-learning cycle, namely Concrete Experience, Reflective Observation, Abstract Conceptualization, and Active Experimentation.

The implementation of ABL approach to learning encourages lecturers to employ a variety of methods in diverse learning environments, one of which is called blended learning. Blended learning is a combination of face to face instruction 
and online learning with the provision of learning materials that mutually support different learning activities [8]-[10].

The blended learning approach requires that lecturers use two or more learning resources or delivery modes such as faceto-face instruction, computer-assisted instruction (offline) and internet-based instruction (online). Chitanana and Erdogan et al. revealed that online learning could significantly improve learning achievement. It requires lecturers to prepare learning materials that accommodate diverse learning activities [9], [11].

The implementation of experiential learning in a blended environment sets up what is called activity-based learning (ABL), which is believed to significantly increase student learning achievement. In fact, the use of blended learning is very important in the implementation of $\mathrm{ABL}$ approach. Through blended learning, students are encouraged to learn actively and comprehensively by involving the cognitive, affective and psychomotor domains. An equal emphasis on all three learning domains will directly impact on the improvement of learning achievement. It can simultaneously improve students' hard skills and soft skills. Such learning can transform students from being passive recipients of knowledge to active participants [12].

In this empirical research, the effectiveness of both the conventional and $\mathrm{ABL}$ method was investigated to reveal the most reliable instructional method for use in higher education. By investigating which of the two methods that are more successful in improving student achievement, the researchers could decide whether or not the use of ABL is suggested and whether another method should be developed.

Compelled by the issues above, this study aimed to investigate the advantages of using the ABL approach incorporating experiential learning in a blended environment over the conventional learning. Since student achievement is strongly influenced by achievement motivation and soft skills, this study also examined the influence of learning methods (ABL and conventional method), level of student's motivation and soft skills on student achievement.

\section{RESEARCH METHOD}

The research was conducted at Universitas Negeri Malang (State University of Malang) in the even semester of 2016/2017The research population consisted of fourthsemester undergraduate students of Civil Engineering who were taking the Construction Management course, namely students from class $\mathrm{C}$ and $\mathrm{D}$. The research participants were obtained using the saturation sampling technique because the experimental and control groups had an equal size; each group consisted of 28 students. This research was an experimental research with a $2 \times 2 \times 2$ factorial design. The types of instruments used in this study included (1) syllabus, (2) lesson plan, (3) worksheet, (4) questionnaire on achievement motivation and soft skills, (5) observation sheet of affective and psychomotor aspects, and (6) achievement and retention test.

The data were collected using two methods namely test and non-test. The test was used to obtain the data of student achievement, while the non-test i.e. questionnaire was used to gather the data of achievement motivation. The study was carried out in two successive stages: (1) survey and exploration to develop teaching materials and (2) experimental research on the developed teaching materials.

The research data were analyzed statistically using a fourway analysis of variance (ANOVA) with the assistance of SPSS Statistics 20. In the hypothesis tests, the significance level $(\alpha)$ used was 0.05 or $5 \%$. The criterion for accepting the null hypothesis (H0) was Sig. $>0.05$.

\section{RESULTS AND DISCUSSION}

\section{A. Effect of Implementing ABL on Student Achievement in Construction Management}

The first hypothesis test showed that the learning achievement of students taught using the ABL model was higher than that of the students taught using the conventional instruction and the result is shown in Table 1.

The mean of learning achievement of students in the experimental group (82.21) without considering achievement motivation and soft skills was better than that of students in the control group (75.21). The significant difference in the average student achievement between the two groups of students indicated that the implementation of ABL positively and greatly affected the student achievement in Construction Management.

According to Ravi and Xavier [13], the ABL could give students the freedom to decide their learning strategies to suit their learning style. Students can select the learning media they prefer and manage their study time. Moreover, they can learn to identify, evaluate learning outcomes, and put knowledge into practice. The implementation of the activitybased learning can serve an initiative to improve critical thinking skills. Fitriana et al. [14] further pointed out that the use of activity-based learning method with worksheets and flashcards could encourage active learning and enhance student achievement.

Moreover, Muntikno [15] suggested that the use of activity-based learning method could increase active participation and interaction during the instructional process, such as students asking questions and expressing opinions, and teachers providing feedback to students. Wahyuningsih [16] found that due to applying the activity-based learning method there was an increase in student pass rate in Mathematics by $42.42 \%$. Malik et al. [17], also argued that the use of the ABL model had a beneficial effect on the improvement of students' generic science skills.

TABLE I. ANOVA ANALYSIS OF ABL IMPLEMENTATION

\begin{tabular}{|l|l|l|l|l|l|l|}
\hline & \multirow{2}{*}{ Mean } & \multirow{2}{*}{$\begin{array}{c}\text { Std. } \\
\text { Deviation }\end{array}$} & \multirow{2}{*}{$\begin{array}{c}\text { Mean } \\
\text { Square }\end{array}$} & N & $\begin{array}{c}\text { F } \\
\text { Change }\end{array}$ & $\begin{array}{c}\text { Sig. F } \\
\text { Change }\end{array}$ \\
\hline ABL & 82.21 & 5.174 & \multirow{2}{*}{507.25} & 28 & 30.532 & .000 \\
\hline Conventional & 75.21 & 3.500 & & 28 & & \\
\hline
\end{tabular}


TABLE II. ANOVA ANALySIS OF ACHIEVEMENT Motivation

\begin{tabular}{|c|c|c|c|c|c|c|c|}
\hline & \multirow[b]{2}{*}{$\begin{array}{c}\text { Achie } \\
\text { veme } \\
\text { nt } \\
\text { Motiv } \\
\text { ation }\end{array}$} & \multirow{2}{*}{$\begin{array}{c}\text { Mea } \\
\mathbf{n}\end{array}$} & \multirow{2}{*}{$\begin{array}{c}\text { Std. } \\
\text { Deviati } \\
\text { on }\end{array}$} & \multirow{2}{*}{$\begin{array}{c}\text { Mean } \\
\text { Square }\end{array}$} & \multicolumn{3}{|c|}{ Change Statistics } \\
\hline & & & & & $\mathbf{N}$ & $\begin{array}{c}\text { F } \\
\text { Chan } \\
\text { ge }\end{array}$ & $\begin{array}{c}\text { Sig. F } \\
\text { Chang } \\
\text { e }\end{array}$ \\
\hline \multirow[t]{2}{*}{$\mathrm{ABL}$} & Low & 82.57 & 5.249 & \multirow[t]{4}{*}{34.268} & 7 & \multirow{4}{*}{2.061} & \multirow{4}{*}{.018} \\
\hline & High & 84.14 & 4.776 & & 21 & & \\
\hline \multirow{2}{*}{$\begin{array}{l}\text { Conve } \\
\text { ntional }\end{array}$} & Low & 74.47 & 3.281 & & 11 & & \\
\hline & High & 76.36 & 3.668 & & 17 & & \\
\hline
\end{tabular}

In this research, the implementation of the ABL brought about a more significant result than the conventional learning process. Through the ABL, the students had a plenty of opportunity and stimulus to confidently speak up with in class either with peers or with the lecturer. In fact, $A B L$ emphasizes on the development of active participation, critical thinking skills, and creativity. The use of ABL leads to the shift from conventional learning format with one-way communication to active learning. The implementation of ABL positively affects the instructional process not only in secondary education but also in higher education.

The mean of learning achievement of students with high achievement motivation (84.14) in the experimental group was higher than that of students with low achievement motivation (81.57). The average achievement score of students in the control group with high achievement motivation (76.36) was higher than that of the students with low achievement motivation (74.47).

Based on the significant difference in the average student achievement between the two groups of students by considering their achievement motivation, it can be concluded that the group of students with high achievement motivation obtained better learning achievement than those with low achievement motivation, either using the ABL or conventional method. Given this point, student achievement in Construction Management varied depending on the level of achievement motivation.

Rashmi and Prasad [18], suggested that the practical ways to cultivate student achievement motivation are by providing proper learning facilities and giving rewards. The stronger the achievement motivation, the greater the learning achievement, and vice versa [19].

Achievement motivation is demonstrated through effective learning actions that can affect the process of maximizing student's potential. Learning activities only work effectively if individuals are motivated to learn. Students who have a strong level of achievement motivation can generate ideas, aspirations, and efforts to perform more effectively and efficiently. The higher the achievement motivation, the better the academic achievement. This result is in line with Biggs and Tefler in Hamdu [20] stating that lack of motivation is likely to affect the quality of learning achievement adversely. In fact, achievement motivation has a profound impact on student achievement.
The results of the present research indicated that achievement motivation contributed to the prediction of student achievement. This case concurreed wellwith Wena [21], arguing that achievement motivation had a very significant and positive influence on student achievement. Ultimately, achievement motivation can be considered as a predictor of learning achievement since they closely correlate.

As a predictor of achievement, student motivation should be fostered systematically. Lecturers can apply an instructional design that promotes and sustains motivation in the learning process, such as the ARCS Model of Motivational Design proposed by Keller [22]. By doing so, lecturers can cultivate student's motivation and eventually bring about improvement in student achievement.

\section{B. Effect of Soft Skills on Student Achievement in Construction Management}

The third hypothesis test presented that students with high soft skills got higher learning achievement compared to those with low soft skills, both in the experimental group with the ABL and the control group with the conventional instruction shown the Table 3.

The mean of learning achievement of students with high soft skills (84.50) in the experimental group was higher than that of the students with low soft skills (79.17). Moreover, the average achievement score of students in the control group with high soft skills (75.83) was higher than that of the students with low soft skills (74.75).

Based on the significant difference in the average achievement of students between the two groups by considering the aspect of soft skills, it can be concluded that the group of students with high soft skills obtained better learning achievement than that with low soft skills, either using the $\mathrm{ABL}$ or conventional method. In sum, student achievement in Construction Management varied depending on the level of soft skills.

According to Setiani and Rasto [23], improvement in learning achievement and soft skills can be achieved by engaging students actively, attracting their interest and attention, motivating, applying the principle of individuality, and demonstrating or modeling in the learning process.

TABLE III. ANOVA ANALYSIS OF THE EFFECT OF SOFT SKILLS

\begin{tabular}{|c|c|c|c|c|c|c|c|}
\hline & \multirow{2}{*}{$\begin{array}{c}\text { Soft } \\
\text { Skills }\end{array}$} & \multirow[t]{2}{*}{ Mean } & \multirow{2}{*}{$\begin{array}{c}\text { Std. } \\
\text { Devia } \\
\text { tion }\end{array}$} & \multirow{2}{*}{$\begin{array}{c}\text { Mean } \\
\text { Square }\end{array}$} & \multicolumn{3}{|c|}{ Change Statistics } \\
\hline & & & & & $\mathbf{N}$ & $\begin{array}{c}\text { F } \\
\text { Chang } \\
\text { e }\end{array}$ & $\begin{array}{c}\text { Sig. F } \\
\text { Chang } \\
\text { e }\end{array}$ \\
\hline \multirow[t]{2}{*}{$\overline{\mathrm{ABL}}$} & Low & 79.17 & 5.096 & \multirow[t]{4}{*}{75.302} & 12 & \multirow{4}{*}{4.528} & \multirow{4}{*}{.039} \\
\hline & High & 84.50 & 4.017 & & 16 & & \\
\hline \multirow{2}{*}{$\begin{array}{l}\text { Conve } \\
\text { ntional }\end{array}$} & Low & 74.75 & 3.568 & & 12 & & \\
\hline & High & 75.83 & 3.460 & & 16 & & \\
\hline
\end{tabular}


Sutrisno and Karjanto [24], through their research on the implementation of the learning community model (also part of the ABL approach), concluded that the learning community model could improve student participation, achievement, and soft skills. Yulianto [25], suggested that student involvement in organizations positively affected the development of soft skills as well; the more elevated the soft skill level, the better the learning achievement, and vice versa. Mahendra et al. found that soft skills and entrepreneurial knowledge had a positive and significant influence on student entrepreneurial achievement [26].

On the whole, soft skills indeed have a beneficial effect on student achievement. The inclusion of soft skills in the instructional process is thus essential. The better the soft skills of students, the higher the learning achievement.

\section{Interaction Effect of ABL model, Achievement Motivation and Soft Skills on Student Achievement in Construction Management}

The results of the fourth hypothesis test interpreted that there was an interaction effect between the variables. In other words, the use of ABL model, achievement motivation, and soft skills had an impact on student achievement in Construction Management. The existence of a significant interaction among the three factors in this study indicated that they did not influence student achievement individually.

To investigate the group that experienced the greatest benefit from the application of ABL, the researchers compared the average achievement in Construction Management between a group of students employing the $\mathrm{ABL}$ and that receiving the conventional instruction. The average achievement scores are presented in Table 4.

Table 4. shows that the group of students with low achievement motivation, high soft skills and using the ABL method had the highest achievement in Construction Management. It indicated that this group derived the most substantial benefit from the application of $\mathrm{ABL}$; in other words, the most effective learning took place in this group. This result was in line with Fitriana [14], concluding that high and effective teacher-student and student-student interactions in the implementation of $\mathrm{ABL}$ resulted in a conducive environment for students to significantly demonstrate and enhance their abilities, and eventually, an improved learning achievement.

The interaction effect of the use of ABL as well as students' achievement motivation and soft skills on learning achievement in Construction Management implied that achievement motivation and soft skills are the decisive factors to improve the achievement of students learning using the ABL method. In fact, effective instructional method, high levels of motivation and soft skills play powerful roles in shaping the ways in which students achieve the learning outcomes.
TABLE IV. AVERAGE DifFERENCE IN STUDENT ACHIEVEMENT IN CONSTRUCTION MANAGEMENT

\begin{tabular}{|l|l|l|}
\hline \multirow{2}{*}{ Method } & \multicolumn{1}{|c|}{ Low Soft Skills } & \multicolumn{1}{c|}{ High Soft Skills } \\
\cline { 2 - 3 } & $\begin{array}{c}\text { Learning } \\
\text { Achievement }\end{array}$ & $\begin{array}{c}\text { Learning } \\
\text { Achievement }\end{array}$ \\
\hline ABL & 79.17 & 84.50 \\
\hline Conventional & 74.75 & 75.83 \\
\hline Average Difference & 4.42 & 8.67 \\
\hline
\end{tabular}

The conventional and activity-based learning generated very different results. The ABL process provided new knowledge to students through various hands-on experiments and classroom activities, making students participated more in learning. It encouraged students to interact, teach and discuss. Therefore, students with both low achievement motivation and soft skills, or those with high achievement motivation but low soft skills could achieve at high levels by using the ABL method. This result concurred well with Malik et al. [17], stating that the ABL was an appropriate learning model for improving students' generic science skills. Addy et al. further pointed out that there was a positive relationship between the implementation of ABL and the improvement of student achievement [27].

In the conventional instruction, the lecturer as a facilitator occupied a dominant role in the instructional process. The lecturer delivered teaching materials by lecturing, and then provided examples of problems along with problem-solving steps. The lecturer gave different types of exercises and guided students in completing the tasks. The conventional instructional process made the lecturer retained a $n$ absolute control of the classroom and became far more active than students. As a result, students with low levels of achievement motivation and soft skill could not actively participate in learning and hence they had a low achievement. This fact was in good agreement with Pribadi who concluded that in the teacher-centered learning, students acquire passively the knowledge transferred by the teacher [28].

\section{CONCLUSION}

The research results and discussion have led to the following conclusions: (1) there was a significant difference in student achievement in Construction Management between the group of students taught using the ABL method and that of students taught using the conventional method; (2) there was a significant difference in student achievement in Construction Management between the group of students with high achievement motivation and that of the students with low achievement motivation; (3) there was a significant difference in student achievement in Construction Management between the group of students with high soft skills and that of the students with low soft skills; and (4) there was a significant interaction effect of the implementation of the ABL model, achievement motivation and soft skills on student achievement in Construction Management. The group of students learned using the ABL method had the highest achievement in Construction Management. It indicated that this group derived the most substantial benefit from the application of ABL. 
In sum, the implementation of $\mathrm{ABL}$ could bring about improvement in student achievement.

\section{REFERENCES}

[1] Wikipedia, "Activity-based learning in India," 2016. [Online]. Available: https://en.wikipedia.org/wiki/Activitybased_learning_in_India. [Accessed: 17-Jul-2017].

[2] S. F. Petra, "School - Based Activities: A Tool for Student Development," Am. Int. J. Contemp. Res., vol. 4, no. 3, pp. 64-72, 2014.

[3] D. A. Kolb, Experiential learning: Experience as the source of learning and development, Vol. 1. Englewood Cliffs, NJ: Prentice-Hall, 1984.

[4] R. Jayaraman, "Experiential Learning Is The Future of Learning," 2014.

[5] C. A. Downey, "Experiential Learning Projects and Implications for Instruction of Human Subjects Research,” J. Eff. Teach., vol. 13, no. 2, pp. 21-37, 2013.

[6] A. Paolini, "Enhancing Teaching Effectiveness and Student Learning Outcomes," J. Eff. Teach., vol. 15, no. 1, pp. 20-33, 2015.

[7] D. A. Kolb and R. E. Fry, Toward an Applied Theory of Experiential Learning. Cambridge: M.I.T. Alfred P. Sloan School of Management., 1974.

[8] J. M. Carman, "Blended Learning Design: Five Key Ingredients," Agilant Learning, 2005. [Online]. Available http://www.agilantlearning.com/pdf/Blended Learning Design.pdf. [Accessed: 18-Nov-2013].

[9] L. Chitanana, "A constructivist approach to the design and delivery of an online professional development course: A case of the iEarn online course," Int. J. Instr., vol. 5, no. 1, pp. 23-48, 2012.

[10] K. Thorne, Blended Learning: How to integrate online \& traditional learning. London: Kogan Page Publishers, 2003.

[11] Y. Erdogan, S. Bayram, and L. Deniz, "Factors that Influence Academic Achievement and Attitudes in Web Based Education," Int. J. Instr., vol. 1, no. 1, pp. 31-47, 2008.

[12] K. A. Hunt et al., "The Effect of Content Delivery Media on Student Engagement and Learning Outcomes," J. Eff. Teach., vol. 16, no. 1, pp. 5-18, 2016

[13] R. Ravi and P. Xavier, "Activity Based Learning as Self-Accessing Strategy to Promote Learners' Autonomy," J. Educ. Psychol., vol. 1, no. 2, pp. 7-9, 2007.

[14] I. Fitriana, S. Mulyani, and B. Mulyani, "Peningkatan Aktivitas dan Hasil Belajar Siswa Melalui Model Pembelajaran Activity Based Learning Berbantuan Flash Card Dilengkapi LKS Pada Materi Isomer Dan Reaksi Senyawa Hidrokarbon Kelas X SMA Batik 1 Surakarta Tahun Pelajaran 2012/2013," J. Pendidik. Kim., vol. 3, no. 2, pp. 88-95, 2014.

[15] Mutikno, "Metode Pembelajaran Berbasis Aktivitas Meningkatkan Prestasi Belajar Matematika Materi Pokok Operasi Hitung Bilangan
Bulat Siswa Kelas V Semester I Sd Negeri I Kamulan Kecamatan Durenan Kabupaten Trenggalek Tahun 2013/2014," J. Pendidik. Prof., vol. 4, no. 3, pp. 67-77, 2005 .

[16] S. Wahyuningsih, "Penerapan Metode Berbasis Aktivitas Dalam Pembelajaran Matematika untuk Meningkatkan Prestasi Belajar Siswa Kelas IX-D Semester I SMP Negeri I Panggul Kabupaten Trenggalek Tahun 2013," J. Pendidik. Prof., vol. 4, no. 2, pp. 202-214, 2015.

[17] A. Malik, Y. Dirgantara, and A. W. Handayani, "Keterampilan Generiks Sains Siswa Melalui Model Activity Based Learning," in Simposium Nasional Inovasi dan Pembelajaran Sains 2016, 2016.

[18] Rashmi and B. Prasad, "Effect of Achievement Motivation on High and Low Achievers of Secondary School Students: A Comparative Study," Int. J. Basic Adv. Res., vol. 2, no. 6, pp. 133-135, 2013

[19] S. M. Aji, "Pengaruh Motivasi Berprestasi Terhadap Prestasi Belajar Akutansi Siswa Kelas X Akutansi SMKN 1 Batang Tahun Pelajaran 2012/2013," Universitas Negeri Semarang, 2013.

[20] G. Hamdu and L. Agustina, "Pengaruh motivasi belajar siswa terhadap prestasi belajar IPA di sekolah dasar," J. Penelit. Pendidik., vol. 12, no. 1, pp. 90-96, 2011.

[21] M. Wena, "Pengembangan Bahan Ajar Matadiklat Produktif Dengan Model Pembelajaran Peningkatan Dan Pengembangan Intelektual Guna Meningkatkan Kemampuan Pemecahan Masalah dan Life Skill Siswa SMK," APPN. LP2M, Malang, 2013.

[22] J. M. Keller, "First Principles of motivation to learn and e-learning," Distance Educ., vol. 29, no. 2, pp. 337-338, 2008.

[23] F. Setiani and Rasto, "Mengembangkan Soft Skill Siswa Melalui Proses Pembelajaran," J. Pendidik. Manaj. Perkantoran, vol. 1, no. 1, pp. 170176,2016

[24] S. Sutrisno and A. Karjanto, "Peningkatan Soft Skill dan Prestasi Belaja Mahasiswa pada Matakuliah Metodologi Penelitian Melalui Pembelajaran Model Learning Community Teknologi dan Kejuruan 37(1): 25-38.," Teknol. dan Kejuru., vol. 37, no. 1, pp. 25-38, 2014.

[25] A. Yulianto, "Pengaruh Keaktifan Siswa Berorganisasi Terhadap Peningkatan Soft Skills dan Prestasi Belajar Siswa Kelas XI Kompetensi Keahlian Teknik Pemesinan SMK Muhammadiyah Prambanan Tahun Ajaran 2014/2015," Universitas Negeri Yogyakarta, 2015

[26] C. Mahendra, Siswandari, and N. Hamidi, "Pengaruh Soft Skills dan Pengetahuan Kewirausahaan terhadap Prestasi Belajar Kewirausahaan," Tata Arta, vol. 2, no. 2, pp. 145-157, 2016

[27] Department for International Development, "Transforming Learning Outcomes through a Learner Centred Pedagogy: Moving Toward a Ghanaian Activity Based Learning Concept and Framework," Reading, UK, 2012.

[28] Pribadi, M. Wena, and Sugiyanto, "Pengembangan Bahan Ajar Struktur Baja dengan Metode Pembelajaran Inovatif Guna Meningkatkan Hasi Belajar Mahasiswa," Penelitian Hibah Bersaing. LP2M, Malang, 2016. 